\title{
The Effect of Methionine on Performance, Carcass Characteristics and Gut Morphology of Finisher Broilers under Tropical Environment Conditions
}

\author{
Nazim Rasul Abdulla ${ }^{1,6}$, Mohamed Idris Alshelmani ${ }^{2,5}$, Teck Chwen Loh $^{1,2}$, Hooi Ling Foo ${ }^{3,4}$ and Mohamad Amirul Zainudin ${ }^{1}$ \\ ${ }^{l}$ Department of Animal Science, Faculty of Agriculture; \\ ${ }^{2}$ Institute of Tropical Agriculture and Food Security; \\ ${ }^{3}$ Department of Bioprocess Technology, Faculty of Biotechnology and Biomolecular Sciences; \\ ${ }^{4}$ Institute of Bioscience, Universiti Putra Malaysia, 43400 UPM Serdang, Selangor, Malaysia. \\ ${ }^{5}$ Department of Animal Production, Faculty of Agriculture, University of Benghazi, Benghazi, Libya. \\ ${ }^{6}$ Department of Animal Resource, Salahaddin University, Erbil, Kurdistan Region, Iraq. \\ *Corresponding author's Email: mohammed.alshelmani@uob.edu.ly; ORCID: 0000-0003-3891-4003
}

Received: 18 Feb. 2020

Accepted: 23 Mar. 2020

\begin{abstract}
The present study was conducted to determine the effect of DL- and L-methionine on growth performance, carcass characteristics, and gut morphology during the finisher phase in the tropical environment. A total of 560 one-day-old broiler chicks (Cobb 500) were purchased and raised for 35 days. The chicks were divided into four dietary treatments with seven replicates (20 birds per replicate). The basal diet was offered to the chickens during the starter and finisher phases. The DL-methionine was supplemented to the finisher diet as at $0.260 \%$ (T1) and $0.179 \%$ (T2). Correspondingly, the L-methionine was supplemented to the finisher diet with the same ratios; $0.260 \%$ (T3) and $0.179 \%$ (T4). The findings revealed no significant differences in growth performance between the two forms of methionine. The obtained results indicated no significant differences in carcass characteristics, the villi heights and crypt depth among the dietary treatments. In conclusion, DL-methionine can be used in broiler nutrition as substitute for L- methionine which is more expensive in poultry industry.
\end{abstract}

Key words: Carcass characteristics, Growth performance, Gut morphology, Methionine, Tropical environment

\section{INTRODUCTION}

The protein content is one of the major factors that affect the productivity of farm animals. Supplementation of animal diets with amino acids to enhance the quality of dietary protein or to replenish the amino acid pool is a common practice in monogastrics.

Methionine (Met) is an essential amino acid in farm animals. It is known as a first limiting amino acid in poultry (Thakur, et al., 2016, Wen, et al., 2017). Adequate levels of dietary Met is required to support the optimum growth (Vinod Kumar and Mandal, 2005) and carcass yield of fast-growing commercial broilers (Ojano-Dirain and Waldroup, 2002). The Met is also capable to enhance growth, maximize meat yield, reduce carcass fat and balance nutrient intake. Routinely, supplemented Met is mostly provided as DL-Met (99\% purity powder), which contains 50\% L-Met and 50\% D-Met. D-Met can be completely absorbed by the intestine (D'Aniello, et al., 1993). Primarily in the liver or kidney, D-Amino Acid Oxidase (DAAO) converts D-Met to L-Met. Literature has clearly demonstrated that DL-Met has $100 \%$ nutritional value compared with L-Met in broiler chicken production. Because the effectiveness of DAAO is very low in the young birds (D'Aniello et al., 1993), some reports argued that DL-Met might not efficiently meet the intestinal cell requirements for young chickens during the first pass metabolism compared with L-Met (Shen, et al., 2015). Thus, the objective of the current study was to evaluate the effect of dietary supplementation of DL-Met and L-Met on broiler growth performance.

\section{MATERIALS AND METHODS}

\section{Ethical approval}

The feeding trial was conducted under the guidelines of the Research Policy on Animal Ethics of the Universiti Putra Malaysia.

\section{Birds and experimental diets}

A total of 560 male broilers (Cobb 500) one-day-old chicks were obtained from a local commercial hatchery and raised for 35 days in 28 deep litter pens. The chicks 
were weighed and randomly distributed into four treatment groups. Each treatment group was divided into seven replicates with 20 chicks for each replicate. The DL-Met was supplemented in the finisher diet as follows: $\mathrm{T} 1=$ $0.260 \%$, $\mathrm{T} 2=0.179 \%$. Correspondingly, the L-Met was supplemented in the finisher diet with the same ratios to obtain T3=0.260\%, and T4 $=0.179 \%$. (Table 1 ). The feed was provided as a mash form, and the drinking water and feed were offered ad libitum for 35 days. The diets were formulated based on the content of amino acids analyzed by Evonik Company (Singapore). The lighting was continued 24 hours per day. The chicks were vaccinated against Newcastle disease, infectious bronchitis infectious and bursal disease vaccine as described by Alshelmani, et al. (2017). The birds were fed with starter diets from 0-14 days, and finisher diet from 15-35 days.

\section{Samples and data collection}

Body weight was measured individually, and feed intake was recorded for each replicate every week. Body Weight Gain (BWG) was calculated, and Feed Conversion Ratio (FCR) was calculated. On 35 days, two birds were randomly selected from each replicate to measure carcass quality and collect the small intestine.

\section{Morphology of small intestine}

The procedure of gut morphology was conducted based on the described method by Alshelmani, et al. (2016). The villi height and crypt depth were measured in the duodenum, jejunum, and ileum. Briefly, samples were taken from the middle part of the duodenum loop, the midway between the duodenum and Meckel's diverticulum for jejunum and the midway between jejunum part and ileocecal junction for ileum. The samples were flushed with $10 \%(\mathrm{v} / \mathrm{v})$ formalin buffer and kept in formalin for further analysis.

\section{Statistical analysis}

The experimental design was applied based on a $2 \mathrm{x}$ 2 factorial completely randomized design following GLM procedures of statistical analytical system (SAS, 2003). Each pen considered as an experimental unit for feed intake and FCR, whereas individual BWG was considered as the experimental unit. When significant effects were found, comparison among the treatments was applied by Tukey's test with a probability of $5 \%(\mathrm{p}<0.05)$. The statistical model was: $Y_{i j k}=\mu+\alpha_{i}+\beta_{j}+\alpha \beta_{i j}+E_{i j k}$. Where $\mathrm{Y}_{i j k}$ is dependent variable; $\mu$ is general mean; $\alpha_{i}$ is effect of Met form; $\beta_{j}$ is effect of Met level; $\mathrm{E}_{i j k}$ is experimental error; $\alpha \beta_{i j}$ is effect of the interaction between Met form and Met level.
Table 1. The composition of experimental finisher diets (15-35 days)

\begin{tabular}{|c|c|c|c|c|}
\hline \multirow{2}{*}{ Ingredient (\%) } & \multicolumn{4}{|c|}{ Dietary treatments } \\
\hline & T1 & $\mathrm{T} 2$ & $\mathrm{~T} 3$ & $\mathrm{~T} 4$ \\
\hline Yellow corn & 57.90 & 57.96 & 57.90 & 57.96 \\
\hline Soybean meal $48 \%$ & 28.17 & 28.16 & 28.17 & 28.16 \\
\hline Palm oil & 4.98 & 5.01 & 4.98 & 5.01 \\
\hline Wheat bran & 5.00 & 5.00 & 5.00 & 5.00 \\
\hline $\mathrm{DCP}^{1} 18 \%$ & 1.66 & 1.66 & 1.66 & 1.66 \\
\hline Calcium carbonate & 0.94 & 0.94 & 0.94 & 0.94 \\
\hline Sodium bicarbonate & 0.250 & 0.252 & 0.250 & 0.252 \\
\hline Salt & 0.248 & 0.247 & 0.248 & 0.247 \\
\hline DL-Methionine & 0.260 & 0.179 & 0 & 0 \\
\hline L-Methionine & 0 & 0 & 0.260 & 0.179 \\
\hline L-Lysine & 0.186 & 0.186 & 0.186 & 0.186 \\
\hline L-Threonine & 0.080 & 0.080 & 0.080 & 0.080 \\
\hline Valine & 0.026 & 0.026 & 0.026 & 0.026 \\
\hline Vitamin premix ${ }^{a}$ & 0.100 & 0.100 & 0.100 & 0.100 \\
\hline Mineral premix ${ }^{\mathrm{b}}$ & 0.150 & 0.150 & 0.150 & 0.150 \\
\hline Choline chloride & 0.050 & 0.050 & 0.050 & 0.050 \\
\hline Total & 100.00 & 100.00 & 100.00 & 100.00 \\
\hline \multicolumn{5}{|l|}{ Nutrient values (\%) } \\
\hline $\begin{array}{l}\text { Metabolizable energy } \\
(\mathrm{kcal} / \mathrm{kg})\end{array}$ & 3050 & 3050 & 3050 & 3050 \\
\hline Crude protein $(\%)$ & 18.87 & 18.82 & 18.87 & 18.82 \\
\hline Crude fat $(\%)$ & 8.55 & 8.59 & 8.55 & 8.59 \\
\hline Crude fiber $(\%)$ & 3.46 & 3.46 & 3.46 & 3.46 \\
\hline Calcium (\%) & 0.89 & 0.89 & 0.89 & 0.89 \\
\hline Available phosphorus (\%) & 0.40 & 0.40 & 0.40 & 0.40 \\
\hline Digestible lysine (\%) & 1.03 & 1.03 & 1.03 & 1.03 \\
\hline Digestible methionine (\%) & 0.50 & 0.42 & 0.50 & 0.42 \\
\hline $\begin{array}{l}\text { Digestible methionine+ } \\
\text { cysteine }\end{array}$ & 0.77 & 0.69 & 0.77 & 0.69 \\
\hline Digestible threonine (\%) & 0.67 & 0.67 & 0.67 & 0.67 \\
\hline Digestible tryptophan (\%) & 0.20 & 0.20 & 0.20 & 0.20 \\
\hline Digestible arginine (\%) & 1.14 & 1.14 & 1.14 & 1.14 \\
\hline
\end{tabular}

${ }^{a}$ Mineral premix provided per kilogram of the diet: Fe $100 \mathrm{mg}$; Mn 110 $\mathrm{mg}$; Cu $20 \mathrm{mg}$; Zn $100 \mathrm{mg}$; I $2 \mathrm{mg}$; Se $0.2 \mathrm{mg}$; Co $0.6 \mathrm{mg}$. ${ }^{\text {bVitamin mix }}$ provided per kilogram of the diet: retinol $2.00 \mathrm{mg}$; cholecalciferol $0.03 \mathrm{mg}$; $\alpha$-tocopherol $0.02 \mathrm{mg}$; menadione $1.33 \mathrm{mg}$; cobalamin $0.03 \mathrm{mg}$; thiamine $0.83 \mathrm{mg}$; riboflavin $2 \mathrm{mg}$; folic acid $0.33 \mathrm{mg}$; biotin $0.03 \mathrm{mg}$; pantothenic acid $3.75 \mathrm{mg}$; niacin $23.3 \mathrm{mg}$; pyridoxine $1.33 \mathrm{mg}$. $\mathrm{T} 1=$ $0.260 \%$ DL-methionine; T2 $=0.179 \%$ DL-methionine; $\mathrm{T} 3=0.260 \% \mathrm{~L}$ methionine; $\mathrm{T} 4=0.179 \%$ L-methionine

\section{RESULTS AND DISCUSSION}

\section{Growth performance}

Table 2 shows the growth performance of broiler chickens fed diets supplemented with different levels and forms of Met. The BWG, feed intake and FCR were not significantly ( $>0.05)$ different among the dietary treatments, regardless of the forms and levels of Met used. The findings are consistent with Shen et al. (2015) who reported no significant difference was found between 
broilers fed diets fortified with DL-Met compared to birds fed diet fortified with L-Met. The results are also in agreement with the findings obtained by Lim (2015) who investigated the bioavailability of L-Met on nursery pigs. The previous study evaluated the DL-Met and L-Met on broiler or pigs and indicated that availability of L-Met was better than DL-Met only at the first seven days of age. The literature attributed findings to the expression of DAAO which found to be very low in the young birds. This enzyme is responsible for converting the D-form of Met to L-form to be utilized by the animal. The expression of this enzyme increase after the first week of age. Therefore, it seems that bioavailability of DL-Met and L-Met are similar to each other regarding growth performance and carcass quality. Another point to consider is that DL-Met supplementation provided a significant improvement in body weight and BWG compared to herbomethione in a comparable study by Kaur et al. (2013).

\section{Carcass traits}

The effect of different levels and forms of Met on carcass and breast yield in broiler chickens is shown in table 3. No significant difference ( $p>0.05$ ) was shown on carcass and breast yield among the dietary treatments irrespective of the forms and levels of Met used in the present study. The results are in agreement with $\mathrm{Li}$, et al. (2017), who reported that no significant differences in carcass yield in pigs fed different levels of diet fortified with L-Met. The results are also consistent with El-Faham, et al. (2017), who reported that there was no difference among groups of broiler chickens fed diet fortified with different forms of Met. The results are also in agreement with Kaur et al., (2013), who mentioned that no significant difference in carcass or breast yields between herbomethione and DL-Met supplemented to the commercial broiler chickens.

\section{Morphology of small intestine}

There was an interaction between the form and level of methionine on villus height in the jejunum and crypt depth in the ileum (Table 4), whereas the interaction was observed on crypt depth in jejunum. The higher villus height was shown on birds fed diet supplemented with $0.179 \%$ L-Met in the finisher phase in comparison with the other groups. The increase of villus height could be attributed to the low levels of methionine. The observations corroborate with Sterling, et al. (2005) who referred that broiler fed low methionine diet showed an increase in villus height compared with group of chickens fed a basal diet.

Table 2. Growth performance of finisher broiler chickens fed diets fortified with different levels and forms of methionine.

\begin{tabular}{|c|c|c|c|}
\hline \multirow{2}{*}{$\begin{array}{l}\text { Dietary } \\
\text { treatments }\end{array}$} & $\begin{array}{l}\text { Body weight } \\
\text { gain }^{\text {a }}(\mathrm{g})\end{array}$ & $\begin{array}{c}\text { Feed intake }^{b} \\
\text { (g/bird) }\end{array}$ & FCR $^{b}$ \\
\hline & $15-35$ days & $15-35$ days & 15-35 days \\
\hline $\mathrm{T} 1$ & 1459.19 & 2458.42 & 1.688 \\
\hline $\mathrm{T} 2$ & 1452.41 & 2518.14 & 1.734 \\
\hline $\mathrm{T} 3$ & 1459.97 & 2500.57 & 1.712 \\
\hline $\mathrm{T} 4$ & 1470.31 & 2565.28 & 1.744 \\
\hline $\mathrm{SEM}^{\mathrm{c}}$ & 7.11 & 25.71 & 0.01 \\
\hline \multicolumn{4}{|l|}{ p-value } \\
\hline Methionine Form & 0.51 & 0.40 & 0.49 \\
\hline $\begin{array}{l}\text { Methionine } \\
\text { levels }\end{array}$ & 0.90 & 0.24 & 0.13 \\
\hline Form x Levels & 0.54 & 0.96 & 0.77 \\
\hline
\end{tabular}

Table 3. Effect of different levels and forms of methionine on carcass and breast yield in finisher broiler chickens.

\begin{tabular}{|c|c|c|}
\hline \multirow[b]{2}{*}{ Dietary treatments } & \multicolumn{2}{|c|}{ Carcass Composition $^{\text {a }}$} \\
\hline & $\begin{array}{c}\text { Carcass yield } \\
(\%)\end{array}$ & $\begin{array}{c}\text { Breast yield } \\
(\%)\end{array}$ \\
\hline $\mathrm{T} 1$ & 70.18 & 36.68 \\
\hline $\mathrm{T} 2$ & 69.58 & 35.20 \\
\hline $\mathrm{T} 3$ & 69.94 & 35.74 \\
\hline $\mathrm{T} 4$ & 69.40 & 36.01 \\
\hline SEM $^{\mathrm{b}}$ & 0.25 & 0.26 \\
\hline \multicolumn{3}{|l|}{ p-value } \\
\hline Methionine Form & 0.690 & 0.904 \\
\hline Methionine levels & 0.275 & 0.244 \\
\hline Form $x$ Levels & 0.945 & 0.095 \\
\hline
\end{tabular}

Table 4. Effect of different levels and forms of methionine.

\begin{tabular}{|c|c|c|c|c|c|c|}
\hline \multirow{2}{*}{ Parameter } & \multicolumn{4}{|c|}{ Dietary treatments } & & \multirow{2}{*}{$\begin{array}{c}\text { p- } \\
\text { value }\end{array}$} \\
\hline & T1 & T2 & T3 & T4 & SEM $^{\mathrm{c}}$ & \\
\hline \multicolumn{7}{|l|}{ Villus height $^{\text {b }}$} \\
\hline Duodenum & 921.38 & 968.59 & 747.27 & 803.53 & 74.17 & 0.069 \\
\hline Jejunum & 775.14 & 707.57 & 431.32 & 675.92 & 47.86 & 0.002 \\
\hline Ileum & 475.68 & 351.54 & 488.47 & 530.93 & 28.52 & 0.006 \\
\hline \multicolumn{7}{|l|}{ Crypt depth } \\
\hline Duodenum & 65.79 & 71.20 & 69.39 & 74.59 & 4.87 & 0.493 \\
\hline Jejunum & 79.52 & 68.56 & 73.24 & 103.59 & 6.43 & 0.104 \\
\hline Ileum & 74.97 & 77.54 & 85.59 & 75.79 & 4.12 & 0.303 \\
\hline
\end{tabular}




\section{CONCLUSION}

Based on the current findings, no significant differences between the methionine forms were found, it can be concluded that the DL-Met can be utilized by broiler chickens likewise the L-Met.

\section{Authors' contributions}

All authors participated equally in designing, sampling, analyzing of results and writing the paper.

\section{Competing interests}

The authors declare that there is no conflict of interest.

\section{REFERENCES}

Alshelmani MI, Loh TC, Foo HL, Sazili AQ and Lau WH. (2016). Effect of feeding different levels of palm kernel cake fermented by paenibacillus polymyxa atcc 842 on nutrient digestibility, intestinal morphology, and gut microflora in broiler chickens. Animal Feed Science and Technology. 216: 216-224. Available at: http://www.sciencedirect.com/science/article/pii/S03778401163012 49.

Alshelmani MI, Loh TC, Foo HL, Sazili AQ and Lau WH. (2017). Effect of feeding different levels of palm kernel cake fermented by paenibacillus polymyxa atcc 842 on broiler growth performance, blood biochemistry, carcass characteristics, and meat quality. Animal Production Science. 57 (5): 839-848. Available at: http://www.publish.csiro.au/paper/AN15359.

D'Aniello A, D'Onofrio G, Pischetola M, D'Aniello G, Vetere A, Petrucelli L and Fisher GH (1993). Biological role of d-amino acid oxidase and d-aspartate oxidase. Effects of d-amino acids. Journal of Biological Chemistry. 268 (36): 26941-26949.

El-Faham A, Ali NG and Abdelaziz M (2017). Effects of dietary threonine level, methionine sources, sex of broiler chicks and their interactions on carcass tissue distribution and chemical composition. Egyptian Poultry Science Journal. 37 (1): 155-167.

Kaur D, Nagra SS, Sodhi S and Dwivedi P (2013). Comparative performance of commercial broilers fed herbomethione $\AA$ as a replacement for dl-methionine in diet. Journal of Applied Animal $\begin{array}{llll}\text { Research. } & 41 & \text { (4): } & 410-416 .\end{array}$ https://doi.org/10.1080/09712119.2013.792731.

Li Y, Zhang H, Chen YP, Ying ZX, Su WP, Zhang LL and Wang T (2017). Effects of dietary 1-methionine supplementation on the growth performance, carcass characteristics, meat quality, and muscular antioxidant capacity and myogenic gene expression in low birth weight pigs1. Journal of Animal Science. 95 (9): 3972 3983. DOI: http://dx.doi.org/10.2527/jas.2017.1652.

Lim J (2015). Evaluation of 1-methionine bioavailability in nursery pigs. MSc.Thesis, University of Kentuky, USA.

Ojano-Dirain C and Waldroup P (2002). Evaluation of lysine, methionine and threonine needs of broilers three to six week of age under moderate temperature. International Journal of Poultry Science. 1 (1): 16-21.

SAS. 2003. Statistical analytical system. SAS Institute Inc., Cary, NC, USA.

Shen Y, Ferket P, Park I, Malheiros R and Kim S (2015). Effects of feed grade l-methionine on intestinal redox status, intestinal development, and growth performance of young chickens compared with conventional dl-methionine. Journal of Animal Science. 93 (6): 2977-2986.

Sterling K, Vedenov D, Pesti G and Bakalli R (2005). Economically optimal dietary crude protein and lysine levels for starting broiler chicks. Poultry Science. 84 (1): 29-36.

Thakur R, Mandal A and Yadav A (2016). Interaction of oxidative feed sanitizer with dietary methionine on growth and immuneresponsiveness of broiler chickens. The Indian Journal of Animal Sciences. 86 (11): 1318-1322.

Vinod Kumar AE and Mandal B (2005). Response of broiler chicks fed high tannin sorghum diets supplemented with dl-methionine. The Indian Journal of Animal Sciences. 75 (12): 1417-1422.

Wen C, Jiang XY, Ding LR and Wang TandZhou YM. (2017). Effects of dietary methionine on growth performance, meat quality and oxidative status of breast muscle in fast- and slow-growing broilers. Poultry Science. $96 \quad$ (6): 1707-1714. DOI: http://dx.doi.org/10.3382/ps/pew432. 